\title{
Transnational Migrant Workers' Life: Paguyuban Seruni's Strategy to Solve Migrant Workers' Problems Overseas by Using Online Media
}

\author{
Sri Wijayanti \\ Lecturer at International Relations Department \\ Faculty of Social and Political Sciences \\ Universitas Jenderal Soedirman, Purwokerto, Indonesia \\ yantietaslim@yahoo.com
}

\author{
Nurul Azizah Zayzda \\ Lecturer at International Relations Department \\ Faculty of Social and Political Sciences \\ Universitas Jenderal Soedirman, Purwokerto, Indonesia \\ zayzda.nurulazizah@gmail.com
}

\begin{abstract}
This paper discusses about the role of online media of Paguyuban Seruni- a migrant workers association- in helping Indonesian migrant workers. This website was created to give any relevant information to the community and to help migrant worker overseas.

This study is a qualitative research which applied in-depth interview with the members of Paguyuban Seruni. The interviews focus on how the media online has helped the migrant workers in dealing with various migrant-related problems. Interestingly, the media online helps not only the community members, but also other migrants working overseas in overcoming their problems. It can be implied that the online media marks the transnational aspect of migrant workers by establishing networks for them where they can connect across borders, interact, share ideas, and even solve problems together by the use of information technology. In this sense, the concept of digital diaspora was used to help explaining the phenomenon.
\end{abstract}

Keywords - migrant workers;transnationalism;migrant politics; digital diaspora.

\section{I.INTRODUCTION}

Indonesia is one of the countries with a considerably high number of migrant workers, generally referred as Buruh Migran Indonesia (Indonesian Migrant Workers/ BMI). ${ }^{1}$ Economic factors resulting from the lack of jobs in this country is one of the factors that encourage migrants to seek employment abroad. The desire to improve and enhance the well-being of the family is the reason they left their homeland and families to work outside the country.

In the era of globalization where the interaction and interconnection around the world increases, the role of the

${ }^{1}$ According to BNP2TKI data accessed in November 282015 from www.bnp2tki.org, in 2011, the number of BMI working abroad amount up to 586.802, in 2012 this number decreased to 494.609 migrant workers. In 2013, the number increased again to 512.168 and in 2014, the number was 429.872 orang, and per October the number was 232.818 . community (non state actors) are increasingly significant in the global and national levels. Advances in technology and the invention of the internet has connected people and other people of different places, different countries and even different continents. In the case of BMI, BMI community can help the problems that take place abroad. One possibility is to make the website and use facebook as a media advocacy to address the problems of migrant workers abroad. One example of use of the website by a community of migrant workers is the online media owned by the Society of Indonesian Migrant Workers 'Paguyuban Seruni' in Banyumas. This website was originally created to inform the activities of the Society of BMI 'Paguyuban Seruni'. In its development, this website is one of the media to deal with cases BMI abroad which were not only coming from Banyumas, but also from other districts who work abroad. The interface of website http://www.seruni.or.id/ who have the "contact us" and link to their facebook page give space to the BMI abroad to denounce the problems they face. In 2015, they have received 15 cases of complaints by BMI. By utilizing a network owned by the Paguyuban Seruni, a total of six cases have been handled, and the rest are still in the process (interview Narsidah, 11.12.2015). This article will discuss about the use of information technology as a medium to help problem BMI abroad.

\section{II.METHOD}

The subject of the previous research is the person who join Paguyuban SERUNI (migrant workers community). The research was conducted using qualitative method, instruments used in the research including in-depth interviews; participant observations and literatures studies. Interactive analysis model is the analytical model used in the research.

\section{III.DISCUSSION \\ A.Transnationalism, grass root association technology \\ Schiller (2010) explains that there are other perspectives that can be used to study the phenomenon of migration. One is the perspective of global power (power global perspective) that understands immigrants not as a stranger in a country, but}


as an actor that connects the realm of local presence, the people, the processes that occur globally (Schiller, 2010: 127). This approach is referred to the use of the term space/domains/transnational social transformation (Faist, 2010: 11), or in general, transnational approach.

Transnational migration studies focus on a series of networks of social relations or also called the social aspects (social field), or the space for the exchange of ideas, practices and resources (Schiller and Levitt, 2004: 1008-1009). Basch, Glick-Schiller and Blank (2009) has defined transnationalism in migration studies as "the process by which immigrants form and maintain social relationships within the community foundation that connects their origin with the communities where they are located (migrate)". The foundation for the approach of transnationalism in migration studies is the fact that social relations are formed by immigrants today have passed the boundaries of geography, culture and politics (Basch, Glick-Schiller and Blanc, 2009: 263).

Utilization of information technology in the lives of immigrants represent the 'fluidity' of life transnational migrant groups, ie, when the movement of migrants are able to utilize the existing technological development. Here in particular information technology serves to connect immigrants to form communities. This phenomenon in some studies is referred as "digital diaspora" (Brinkerhoff, 2009; Laguerre, 2010). Digital Diaspora here is defined as:

"A group of immigrants or descendants of an immigrant population using the interconnectedness of information technology to participate in a virtual network with contacts with different purposes, whether it is political, economic, social, religious and communication, be it with regard to homeland country or host country, or both, with the track itself" (Laguerre, 2010: 50).

With information technology, immigrants can establish solidarity and share the problems and benefits, and general information technology can help to carry out certain activities (Brinkerhoff, 2009). In this case, information technology helps to:

1. Facilitate the formation of a common identity

2. Facilitate networking and organizing communication between individuals and groups

3. Provide information to actors outside the group

4. Facilitate framing issues and strengthening related activities

(Brinkerhoff, 2009: 47).

The following discussion looks further into the life of migrant workers affected by the development of information technology. By examining the use of the technology by community of migrant workers in Banyumas, it will be analysed how the activities demonstrate migrants politics. The main actor being discussed here is the Paguyuban Seruni itself, which under civil society studies can be categorized as a grassroots association.

Kunreuther (2011) explains that grassroots association is constituted by people who are concerned in a particular issue or interest, where solutions are made together in the association by members who join the group voluntarily. The keyword here is grassroots organization encourages participation in solving social problems and works in community level (Kunreuther, 2011: 55-66). In this study, grassroots association, represented by Paguyuban Seruni, connects itself with the global through its activism of working along with migrant workers.

\section{B.The role of Community website}

Paguyuban Seruni of Migrant Workers is an organization founded by former migrant workers in the District of Banyumas. This group was established by group of people that formerly had the same job as a migrant worker. Therefore the organization's management and members were all migrant workers. At the beginning, Paguyuban Seruni aimed to assist its members in providing information regarding safe migration procedures and help them find solution to the problems experienced by the members. In its later development, in addition to advocacy, the Community also include economic activities aimed to improve the welfare of its members. Paguyuban Seruni had several attempts to improve the economy of its members.

Since the year 2012, Paguyuban Seruni used the website http://www.seruni.or.id./ and Seruni Banyumas (facebook's name) which contain the information about the Community members. In the website, the menu 'Contact us' and also include the address of Facebook as a communication medium between Pagyuban Seruni and the readers of the website. This media serves to provide an opportunity for readers to learn more about the Paguyuban Seruni and obtain information about migrant workers and safe migration procedures. Through Paguyuban Seruni, the community establishes contacts with migrants abroad, including migrants in Singapore, Malaysia, Taiwan, Hong Kong, Saudi Arabia, Kuwait, Thailand etc. They link up to develop the organization and seeking information to find solution for the problems of migrant workers.

The media online created by Paguyuban Seruni is a strategy developed to assist migrant workers who experience problems abroad by making use the ease access provided by internet. Below are several examples of how media online has been used by migrant workers, their families and with the facilitation by Paguyuban Seruni, helped the migrants with their issues.

In 2014, the husband of a migrant worker originating from Cilongok, Banyumas, Central Java, asking for help through Seruni website to find his wife working in Hong Kong and whose news or whereabouts have not been heard by the family for a quite long time. After receiving the report, Paguyuban Seruni contacted its partner organization in Hong Kong to find out about the whereabouts of his wife through fecebook. It is known, that the man's wife was in Macau due to change of employers. Although until now, her exact whereabouts remains unknown, Seruni maintains close monitor through communication with the organization in Hongkong.

Another case received by Paguyuban Seruni was a report of a migrant worker who is accused of committing crimes in Kuwait. The person send a message to the Paguyuban Seruni via the facebook to help him with this issue. They are intense to keep in touch on the problems of the migrant workers. Through the intense communication between Seruni and the person, it was known that he had been in prison for 4 years and did not get the attention of the government when he was in prison. Having received the 
report, Paguyuban Seruni asked the district government to commit to finding a solution about it. Together with local government, they urged the central government to give attention to migrant workers who were in prison.

Another case was reported a migrant worker working in Taiwan. She was supposed to work at home that is not too big. But the fact is, she was placed in a very big house and she had to do all the houseworks. She contacted Paguyuban Seruni through facebook. Aside from maintaining communication with the migrant worker, Paguyuban Seruni also contacted the organization of migrant workers in Taiwan $(\mathrm{ATKI})^{2}$ and asked to follow up the issue. Finally, with the cooperation of Paguyuban Seruni and ATKI, they can urge employment agencies for migrant workers to move her elsewhere.

This cases give example of how policy is being challenged by the migrants. The focus here is on the way they connect with people and materialize this relation and communication into solution for their particular problems.

\section{IV.CONCLUSION}

Migrant workers are not passive object in politics where they cannot influence policies. Their simple action and choice that challenges certain situation or policy can be regarded as their political engagement. In the examples given above, there are ways migrant workers may challenge the available policy which affect them. In particular, this study gives example of what is called digital diaspora, the use of information technology by migrants to help pursuing their interests. Herein, the grassroots association presented by Paguyuban Seruni plays a role in connecting migrants among them and their homeland community. There are at least two necessary aspects here in which digital diaspora may be established and play a role in challenging policy. First, the community that build the digital diaspora need to connect with other actors, other grassroots or non-governmental organizations. Second, information technology is utilized as a mean to communicate with migrant workers or any related individuals or groups.

In this study, it is found that digital diaspora have been necessary not only for the migrant workers but also for the families left behind. By asking for assistance and finding solutions through the networking, migrants have indirectly involved in politics of their everyday life. Considering the transnational nature of the migrants, their political engagement has also been a challenge to the notion of sovereignty and boundaries, cause their politics have crossed these boundaries.

\section{REFERENCES}

[1] Basch, L., Glick-Schiller, N. and Blanc, C. S. (2008). Transnational Projects: A New Perspective and Theoretical Premise. Dalam Khagram, S., \& Levitt, P. (2008). The transnational studies reader: Intersections and innovations. New York/London: Routledge.

[2] Brinkerhoff, J. M. (2009). Digital diasporas: Identity and transnational engagement. Cambridge University Press

\footnotetext{
${ }^{2}$ The non governmental organization in Taiwan focuse on migrant workers problems
}

[3] Faist, T. (2010). Diaspora and Transnationalism: What kind of Dance Partners In R. Baubock \& T. Faist (Eds). Diaspora and Transnationalism: Concepts, Theories, and Method. (9-34). Amsterdam: Amsterdam University Press.

[4] Glick Schiller, N. (2010). Global Perspective on Transnational Migration: Theorising migration without Methodological Nationalism. In R. Baubock \& T. Faist (Eds). Diaspora and Transnationalism: Concepts, Theories, and Methods. (109-130). Amsterdam: Amsterdam University Press.

[5] Glick Schiller, N. dan Levitt, P. (2004). Conceptualizing Simultaneity: A Transnational Social Field Perspective on Society. International Migration Review, 38 (3), 1002-1039.

[6] Kunreuther, F. (2011). Grassroots associations. The Oxford handbook of civil society, Oxford/New York: Oxford University Press Inc, 55-67.

[7] Laguerre, M. (2010). Digital diaspora: Definition and models. Diasporas in the new media age: Identity, politics and communities, 4964.

[8] Interviwed with Narsidah on 11.12 .2015 and 23.02.2016 